\title{
Carnitine Status at Birth of Newborn Infants of Varying Gestation
}

\author{
JAYANT P. SHENAI, ${ }^{(26)}$ PEGGY R. BORUM, PETAIAH MOHAN, AND SUSAN C. DONLEVY \\ Department of Pediatrics [J.S., P.M.] and Department of Biochemistry [P.B.], Vanderbilt University Medical Center, \\ and Department of Pediatrics [S.D.], Metropolitan Nashville General Hospital, Nashville, Tennessee, USA
}

Summary

This study assessed and compared the plasma and red blood cell concentrations of carnitine in cord blood samples from preterm $(\leq 36 \mathrm{wk}, n=53)$ and term $(\geq 37 \mathrm{wk}, n=72)$ neonates. The mean $( \pm$ S.E.) plasma carnitine concentration (PL $[\mathrm{C}])$ was significantly higher in preterm than in term neonates $(29.0 \pm 1.8$ versus $22.4 \pm$ $0.8 \mathrm{nmole} / \mathrm{ml} ; P<0.001)$. Likewise, the mean $( \pm$ S.E. $)$ red blood cell carnitine concentration (RBC $[C])$ was significantly higher in preterm than in term neonates $(0.24 \pm 0.02$ versus $0.14 \pm 0.01$ nmole/mg $\mathrm{Hgb} ; P<0.001)$. Both $\mathrm{PL} \mid \mathrm{C}]$ and $\mathrm{RBC}[\mathrm{C}]$ were particularly elevated in extremely immature neonates $(\leq 33$ wk gestation). Linear regression analysis showed a significantly negative correlation between $P L[C]$ and gestational age $(r=-0.332 ; P<$ $0.001)$, and between $\mathrm{RBC}[\mathrm{C}]$ and gestational age $(r=-0.531 ; P$ $<0.001$ ). Approximately $72.2 \pm 1.1 \%$ (mean \pm S.E.) of carnitine in blood was estimated to be contained in the RBC, and $27.8 \pm$ $1.1 \%$ (mean \pm S.E.) of carnitine was estimated to be in the plasma.

\section{Abbreviations}

AGA, appropriate for gestational age

Hgb, hemoglobin

PCV, packed cell volume

PLIC], plasma carnitine concentration

$\mathrm{RBC}$, red blood cell

RBC $[C]$, red blood cell carnitine concentration

SGA, small for gestational age

Carnitine, $\beta-\mathrm{OH}-\gamma$-trimethyl amino-butyric acid, is a quarternary amine that plays an essential role in the oxidation of long chain fatty acids by facilitating their transport across the inner mitochondrial membranes via a carnitine acyltransferase enzyme system $(8,16)$. Improved fatty acid utilization would enhance a neonate's ability to utilize energy, which in turn may potentiate growth. Fatty acid oxidation also plays an important part in the thermogenic function of brown adipose tissue (10). This factor may be of an immense value to the neonate, particularly a sick preterm infant in achieving thermal homeostasis. Animal studies have suggested an important role for carnitine in hepatic ketogenesis (12). Ketones constitute a significant source of metabolic fuel, particularly for utilization by brain in the perinatal period (18). These various studies seem to indicate that carnitine is one of the essential nutrients in the diet of newborn infants (3).

Studies in various animal species have demonstrated a transfer of carnitine from the mother to the fetus during pregnancy and via milk during the postnatal period $(10,11,20)$. The amount of carnitine transferred across the placenta varies with different species. Little is known of carnitine levels during various stages of human gestation. Plasma concentration of carnitine is often used as the parameter for determination of carnitine status. This study was designed to assess and compare the plasma concentrations of carnitine at birth in a group of preterm and term neonates. Additional assessment of RBC concentrations of carnitine in the same group of infants was also undertaken.

\section{MATERIALS AND METHODS}

Subjects: Fifty-three preterm infants, admitted to the neonatal intensive care unit at the Vanderbilt Medical Center, were studied. These infants (male $=30$ and female $=23$ ) were $\leq 36$ wk gestation Their birth weights ranged 790-3010 g. Fourteen of these infants were $\leq 30$ wk gestation and had a mean $( \pm$ S.E.) birth weight of $1100 \pm 48 \mathrm{~g}$. Nineteen infants were 31-33wk and weighed 1620 $\pm 54 \mathrm{~g}$. Twenty infants were $34-36 \mathrm{wk}$ in gestation and weighed $2360 \pm 75 \mathrm{~g}$ at birth. Of these 53 preterm infants, 35 were born to caucasian parents; the remainder with the exception of two Oriental infants were born to black parents. Of the 53 preterm infants, 18 were delivered by cesarean section; the remainder were delivered vaginally. The common indications for abdominal delivery were prematurity and breech presentation. All infants were AGA as their body measurements were within \pm 2.0 S.D. of the mean on standard growth graphs (1).

Sixty-three term infants at the Vanderbilt Medical Center were studied concurrently. These infants (male $=31$ and female $=32$ ) were $\geq 37 \mathrm{wk}$ gestation. Their birth weights ranged $2810-4110 \mathrm{~g}$ (mean \pm S.E., $3390 \pm 47 \mathrm{~g}$ ). Of the 63 term infants, 45 were born to caucasian parents; the remainder with the exception of an Asian Indian and a Mexican infant were born to black parents. Three of the term infants were delivered by cesarean section. Cephalopelvic disproportion was the indication for abdominal delivery. With the exception of seven SGA infants, the remainder were appropriately grown. An additional nine infants (male $=7$ and female $=2$ ) of postterm gestation $(\geq 42 \mathrm{wk})$ were included in the study. All of these infants were caucasian, AGA, and delivered vaginally. Multiple births and neonates with congenital anomalies were excluded from the study. The study was approved by the Committee for the Protection of Human Subjects-Health Sciences of the Institutional Review Board of Vanderbilt University.

Clinical procedures. Informed consent was obtained from the parents of each infant before delivery. Immediately after delivery of the placenta, about $5.0 \mathrm{ml}$ of blood was collected from the separated umbilical cord for carnitine assay. A test tube containing dry heparin was used for blood collection. The PCV and $\mathrm{Hgb}$ concentration were determined by using standard methods. The gestational age of each infant was estimated from the maternal history and by clinical assessment of maturity (7). Accurate measurements of body weight, occipito-frontal circumference, and crown-heel length were obtained from each infant and recorded. A careful clinical examination of the infant was performed to exclude clinically apparent congenital malformations.

Chemical procedures. Blood was separated into plasma and $\mathrm{RBC}$, and the RBC were washed twice with saline with complete removal of the buffy coat. Washed $\mathrm{RBC}$ were broken by addition of an equal volume of deionized water and freezing and thawing two times. Triplicate aliquots of plasma and $R B C$ were assayed for total carnitine by a modification of the method of Cederblad and Lindstedt (5) as described below.

Triplicate aliquots of $\mathrm{L}$-carnitine standard (1.25-15 nmole) and $200 \mu \mathrm{l}$ of the blood sample were incubated in $0.1 \mathrm{~N} \mathrm{KOH}$ at $50^{\circ} \mathrm{C}$ for $30 \mathrm{~min}$ in a final volume of $250 \mu 1$ to hydrolyze acetylcarnitine and acylcarnitine. The samples were cooled and $750 \mu \mathrm{l}$ of $0.6 \mathrm{M}$ 
perchloric acid was added to precipitate protein. After centrifugation, $500 \mu$ l of the supernatant was neutralized with $4 \mathrm{~N} \mathrm{KOH}$ using phenol red as an indicator. These tubes were incubated overnight at $4^{\circ} \mathrm{C}$ and then centrifuged to remove the potassium perchlorate salt. The clear pink supernatant was used for the carnitine assay. Three solutions were used to make an ingredient mix. Solution I was $\left[1-{ }^{14} \mathrm{C}\right]$ acetyl coenzyme $\mathrm{A}$ at a concentration of $3.2 \mu \mathrm{M}$ and a radiospecific activity of $50 \mathrm{mCi} / \mathrm{mmole}$. Solution II was $0.1 \mathrm{mM}$ acetyl coenzyme A prepared in the following manner: $10 \mathrm{mg}$ coenzyme A was dissolved in $500 \mu \mathrm{l}$ of cold $\mathrm{H}_{2} \mathrm{O}$, neutralized with $100 \mu \mathrm{l}$ of $1 \mathrm{M} \mathrm{KHCO}_{3}$, mixed well with $200 \mu \mathrm{l}$ of $0.1 \mathrm{M}$ acetic anhydride and diluted to $80 \mathrm{ml}$ with cold $\mathrm{H}_{2} \mathrm{O}$. Both Solution I and II were stored in aliquots at $-20^{\circ} \mathrm{C}$. Solution III was $1 \mathrm{M}$ potassium phosphate buffer $\mathrm{pH} 7.0$ containing $2 \mathrm{mg} / \mathrm{ml}$ $\mathrm{N}$-ethyl-maleimide to pull the reaction to near completion and thus make the standard curve a straight line. The ingredient mix consisting of 2 volumes of Solution I and 1 volume of Solution II and Solution III was made immediately before use and stored on ice. The reaction tube contained $100 \mu \mathrm{l}$ of carnitine standard and $100 \mu \mathrm{l}$ of the ingredient mix. The reaction was started with 1 unit of carnitine acetyltransferase in a volume of $20 \mu 1$. After incubation at $37^{\circ} \mathrm{C}$ for $30 \mathrm{~min}, 200 \mu 1$ of the reaction mixture was put on a 5 $\times 35 \mathrm{~mm}$ column of Dowex $2 \times 8\left(\mathrm{Cl}^{-}\right)$. The column drained directly into a polyethylene scintillation vial and was washed with 2 aliquots of cold $\mathrm{H}_{2} \mathrm{O}$. Nine $\mathrm{ml}$ of Aqueous Counting Scintillant was added and the vials counted in a liquid scintillation spectrometer.

Statistical analysis. Statistical analysis (mean, S.E. of the mean, linear regression, correlation coefficient, Student $t$ test, and analysis of variance) were performed by using Hewlett Packard HP-55 programmable calculator and the Statistical Package for the Social Sciences computer system.

\section{RESULTS}

The mean plasma carnitine concentration was significantly higher in infants born prematurely than in infants of term gestation (Table 1). The mean plasma carnitine values in preterm infants, $\leq 30 \mathrm{wk}$, and $31 \mathrm{wk}$ through $33 \mathrm{wk}$ in gestation did not differ significantly among the groups (Fig. 1); however, each of these values was significantly higher than the corresponding mean plasma carnitine values for the groups of larger preterm (34 wk through $36 \mathrm{wk}$ ), term ( $37 \mathrm{wk}$ through $41 \mathrm{wk}$ ), and postterm ( $\geq 42$ wk) infants. Linear regression analysis showed a significant negative correlation $(r=-0.332 ; P<0.001)$ between plasma carnitine and gestational age. No significant differences were observed in the mean plasma carnitine concentrations when the neonates were grouped based on sex, race, and growth characteristic (Table 2).

The mean RBC carnitine concentration was significantly higher in infants of preterm gestation than in infants born at term (Table 1). The mean $R B C$ carnitine values in preterm infants, $\leq 30 \mathrm{wk}$, and $31 \mathrm{wk}$ through $33 \mathrm{wk}$ in gestation did not differ significantly among the groups (Fig. 1); however, each of these values was significantly higher than the corresponding mean RBC carnitine value for the group of term infants. The mean RBC carnitine value for the group of larger preterm infants (34 wk through 36 wk) did not differ significantly from the corresponding mean value for the term group. The RBC carnitine concentrations in post-term infants differed significantly only from the values recorded in the group of very immature $(\leq 30 \mathrm{wk})$ neonates. Linear regression analysis showed a significant negative correlation $(r=$ $-0.531 ; P<0.001$ ) between RBC carnitine and gestational age. No significant differences were observed in the mean RBC carnitine concentrations when the neonates were grouped based on sex, race, and growth characteristic (Table 2).

The mean ( \pm S.E.) plasma carnitine concentration of $33.4 \pm 3.8$ $\mathrm{nmole} / \mathrm{ml}$ in neonates delivered by cesarean section was significantly higher than the corresponding mean ( \pm S.E.) value of 23.5 $\pm 0.7 \mathrm{nmole} / \mathrm{ml}$ in infants delivered vaginally $(P<0.01)$. Likewise, the mean $( \pm$ S.E.) RBC carnitine concentration of $0.26 \pm 0.03$ $\mathrm{nmole} / \mathrm{mg} \mathrm{Hgb}$ in neonates delivered by cesarean section was significantly higher than the corresponding mean $( \pm$ S.E.) value of $0.17 \pm 0.01 \mathrm{nmole} / \mathrm{mg} \mathrm{Hgb}$ in infants delivered vaginally $(P$ $<0.001)$. These differences were attributed to the greater number of preterm infants in the group of neonates delivered by cesarean section. The mean ( \pm S.E.) gestational age of $31.5 \pm 0.9 \mathrm{wk}$ in neonates delivered by cesarean section was significantly lower than the mean ( \pm S.E.) gestational age of $37.7 \pm 0.4 \mathrm{wk}$ in neonates delivered vaginally $(P<0.001)$. A comparison of neonates with regard to their plasma and $R B C$ carnitine concentrations failed to show a significant difference when the infants were
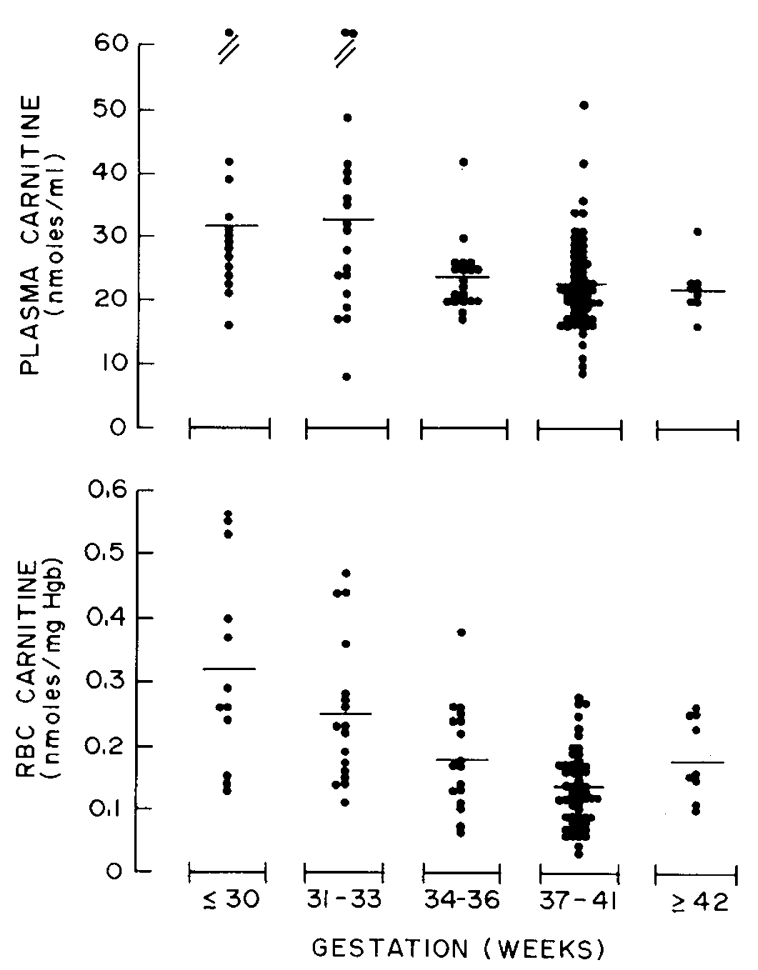

Fig. 1. Plasma and red blood cell (RBC) carnitine concentrations in cord blood in neonates of varying gestation. The solid lines indicate the mean values for each group.

Table 1. Plasma and red blood cell carnitine concentrations in neonates

\begin{tabular}{lccccccc}
\hline \multicolumn{1}{c}{ Group } & $n$ & $\begin{array}{c}\text { Gestation } \\
(\mathrm{wk})\end{array}$ & $\begin{array}{c}\text { Birth weight } \\
(\mathrm{g})\end{array}$ & $\begin{array}{c}\text { Occipito-frontal } \\
\text { circumference } \\
(\mathrm{cm})\end{array}$ & $\begin{array}{c}\text { Crown-heel } \\
\text { length } \\
(\mathrm{cm})\end{array}$ & $\begin{array}{c}\text { Plasma } \\
\text { carnitine } \\
(\mathrm{nmole} / \mathrm{ml})\end{array}$ & $\begin{array}{c}\text { Red blood } \\
\text { cell carnitine } \\
(\mathrm{nmole} / \mathrm{mg} \mathrm{Hgb})\end{array}$ \\
\hline $\begin{array}{l}\text { Preterm } \\
(\leq 36 \mathrm{wk})\end{array}$ & 53 & $32.2 \pm 0.4^{1}$ & $1762 \pm 79^{2}$ & $29.5 \pm 0.3$ & $42.3 \pm 0.6$ & $29.0 \pm 1.8^{3}$ & $0.24 \pm 0.02$ \\
$\begin{array}{l}\text { Term } \\
(\geq 37 \mathrm{wk})\end{array}$ & 72 & $39.9 \pm 0.2$ & $3336 \pm 58$ & $34.5 \pm 0.2$ & $51.1 \pm 0.3$ & $22.4 \pm 0.8$ & $0.14 \pm 0.01$ \\
\hline
\end{tabular}

\footnotetext{
${ }^{1}$ Values are mean \pm S.E.

${ }^{2}$ Body measurements are significantly lower in preterm group $(P<0.001)$.

${ }^{3}$ Carnitine concentrations are significantly higher in preterm group $(P<0.001)$.
} 
Table 2. Plasma and red blood cell carnitine concentrations in neonates

\begin{tabular}{|c|c|c|c|c|c|c|}
\hline \multirow{2}{*}{$\begin{array}{c}\text { Carnitine } \\
\text { concentration }\end{array}$} & \multicolumn{2}{|c|}{ Sex } & \multicolumn{2}{|c|}{ Race } & \multicolumn{2}{|c|}{ Growth pattern } \\
\hline & Male & Female & White & Black & AGA & SGA \\
\hline Plasma $^{1}(\mathrm{nmole} / \mathrm{ml})$ & $\begin{array}{c}26.5 \pm 1.5^{2} \\
(n=68)\end{array}$ & $\begin{array}{c}23.6 \pm 1.0 \\
(n=57)\end{array}$ & $\begin{array}{c}25.2 \pm 1.1 \\
\quad(n=88)\end{array}$ & $\begin{array}{c}25.4 \pm 2.0 \\
\quad(n=33)\end{array}$ & $\begin{array}{r}25.0 \pm 1.0 \\
(n=116)\end{array}$ & $\begin{array}{c}29.8 \pm 4.6 \\
(n=7)\end{array}$ \\
\hline $\begin{array}{l}\text { Red blood cell (nmole/ } \\
\text { mg Hgb) }\end{array}$ & $\begin{array}{c}0.20 \pm 0.01 \\
(n=62)\end{array}$ & $\begin{array}{c}0.17 \pm 0.02 \\
(n=50)\end{array}$ & $\begin{array}{c}0.18 \pm 0.01 \\
(n=80)\end{array}$ & $\begin{array}{c}0.19 \pm 0.02 \\
(n=29)\end{array}$ & $\begin{array}{c}0.19 \pm 0.01 \\
(n=104)\end{array}$ & $\begin{array}{c}0.15 \pm 0.02 \\
(n=6)\end{array}$ \\
\hline
\end{tabular}

${ }^{1}$ Mean values are not different with respect to sex, race, and growth pattern.

${ }^{2}$ Values are mean \pm S.E.

matched for their gestational age. Linear regression analysis showed a significant positive correlation $(r=0.320 ; P<0.001)$ between plasma carnitine and $\mathrm{RBC}$ carnitine.

The relative distribution of carnitine in plasma and $\mathrm{RBC}$ was determined from the carnitine concentrations in the two blood components, $\mathrm{PCV}$ and $\mathrm{Hgb}$ concentrations. The latter values are shown in Table 3. The estimated values for RBC carnitine expressed as a $\%$ of whole blood carnitine from individual infants are shown in Figure 2. Approximately $72.2 \pm 1.1 \%$ (mean \pm S.E.) of carnitine in blood was estimated to be contained in the red blood cells, and $27.8 \pm 1.1 \%$ (mean \pm S.E.) of carnitine was estimated to be in the plasma. These \% did not vary with gestational age, sex, race, growth characteristic, or the mode of delivery of the infants. These estimates do not take into account the carnitine possibly contained in the white blood cells and the platelets, as most of these cells were removed with the RBC washing procedure.

\section{DISCUSSION}

Normal concentration (mean \pm S.D.) of total carnitine in plasma measured by our laboratory in healthy adult humans is $50.6 \pm 11.2 \mathrm{nmole} / \mathrm{ml}(n=272)$ for males and $44.7 \pm 11.9 \mathrm{nmole} /$ $\mathrm{ml}(n=234)$ for females. Decreasing concentrations of carnitine in the blood have been observed in pregnant women with advancing gestation $(11,21)$. There is a paucity of information about plasma carnitine values in children, and in infants including neonates, particularly in premature newborns. This study was designed to assess the plasma total carnitine concentrations in cord blood samples obtained from a large number of newborn infants of varying gestation. This study was also designed to provide additional data on RBC carnitine concentrations. Total carnitine was measured rather than free carnitine or acyl carnitine because the purpose of the study was to determine the carnitine status. The cord blood samples were chosen for analysis to allow determination of the carnitine status of infants at birth, before possible changes induced by postnatal nutritional manipulation and therapeutic intervention.

The cord blood carnitine concentrations reported in this study are similar to the previously published values $(14,15)$. Several mechanisms may be postulated for the higher carnitine concentrations observed in premature infants: $(I)$ enhanced endogenous synthesis of carnitine could account for the higher carnitine levels in blood. The principal site of carnitine synthesis from amino acids lysine and methionine is believed to be the liver (2), and the hepatic $\gamma$-butyrobetaine hydroxylase enzyme activity is often used as a measure of the capacity for carnitine synthesis (2). Data from a limited number of young infants indicate that the hepatic $\gamma$ butyrobetaine hydroxylase activity is only $12 \%$ of the normal adult activity (19). This study and similar observations in experimental animals (9) suggest that the endogenous carnitine synthesis is probably limited, rather than enhanced in immature neonates. (2) Enhanced transplacental transfer of carnitine in earlier stages of pregnancy could result in higher carnitine levels in blood in preterm neonates. The precise mechanism by which carnitine is supplied to the human fetus is not understood; however, studies $(11,14)$ examining the materno-fetal gradients of carnitine and its metabolites seem to suggest that the transplacental transfer is the
Table 3. Packed cell volume and hemoglobin concentrations (mean $\pm S$. . .) in neonates

\begin{tabular}{cccc}
\hline $\begin{array}{c}\text { Gestation } \\
\text { (wk) }\end{array}$ & $n$ & $\begin{array}{c}\text { Packed } \\
\text { cell volume } \\
(\%)\end{array}$ & $\begin{array}{c}\text { Hemoglobin } \\
(\mathrm{g} / \mathrm{dl})\end{array}$ \\
\hline$\leq 30$ & 14 & $50.6 \pm 1.9$ & $16.9 \pm 0.6$ \\
$31-33$ & 19 & $50.5 \pm 1.4$ & $16.8 \pm 0.5$ \\
$34-36$ & 20 & $52.9 \pm 1.4$ & $17.6 \pm 0.5$ \\
$37-41$ & 63 & $57.0 \pm 0.6$ & $19.0 \pm 0.2$ \\
$\geq 42$ & 9 & $57.3 \pm 1.7$ & $19.1 \pm 0.6$ \\
\hline
\end{tabular}

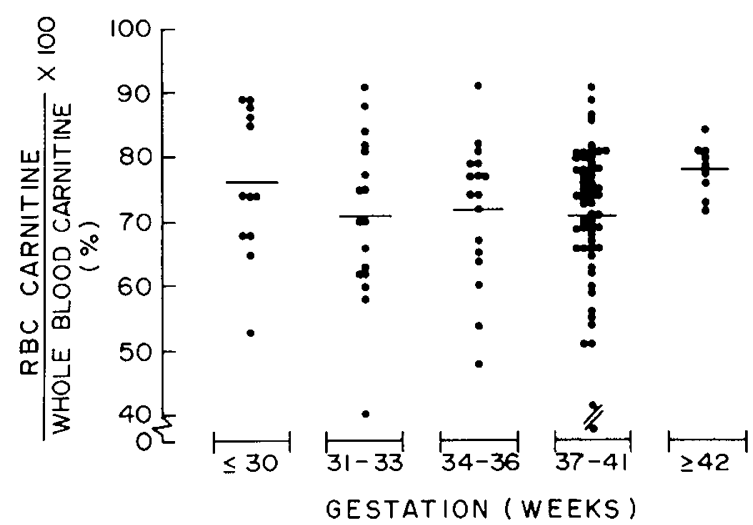

Fig. 2. Estimated values of red blood cell (RBC) carnitine expressed as a $\%$ of whole blood carnitine from individual infants. The solid lines indicate the mean values for each group.

major route by which carnitine is acquired by the human fetus from the mother. It is possible that this transfer of carnitine occurs predominantly in the earlier stages of human pregnancy. Such a scheme would seem to benefit an immature fetus with a limited capacity for endogenous synthesis and with a greater dependence on exogenous sources such as the maternal stores for carnitine acquisition. (3) Reduced carnitine uptake and storage by the tissues could account for the higher carnitine levels in blood. The principal site of carnitine storage is the skeletal muscle, although other tissues such as the heart, adrenal gland, liver, and adipose tissue contain significant amounts of carnitine (13). Our preliminary observations (22) on autopsy specimens obtained from verylow-birth-weight neonates dying within $24 \mathrm{~h}$ of birth show that the concentrations of carnitine in the skeletal muscle, liver, and heart in these immature neonates are very low in comparison to the control values reported for older children (6). Tissue carnitine concentrations in the range reported for systemic carnitine deficiency (23) have been observed in older premature neonates (17). It is therefore possible that the high carnitine concentrations in blood in preterm infants may be a reflection of immaturity of mechanisms for carnitine uptake and storage in the tissues. Further studies are needed to elucidate the specific mechanisms involved in the metabolism of carnitine at the tissue level.

The blood component analyzed most commonly for determination of carnitine status is the plasma. There is little information 
on RBC carnitine concentrations. It is apparent from our observations that a higher \% of carnitine in blood is contained in the $\mathrm{RBC}$ than in the plasma. A sulfhydral-dependent protein, which specifically binds carnitine, has been recently identified and isolated in the membrane of the human RBC (4). Such a specific transport carrier for carnitine has not been identified in the plasma. The higher \% of carnitine in the RBC may be the result of the binding of carnitine to the RBC membrane. It is possible that the RBC may play an important role in the transport of carnitine to the tissues. Further studies are needed to elucidate the specific transport mechanism and to ascertain quantitative and qualitative differences in the RBC-carnitine binding in neonates, children and adults. Based on our observations, we suggest that it is important to include RBC carnitine concentrations in future studies attempting to define the carnitine status of an individual.

In conclusion, the higher concentrations of carnitine in blood in preterm neonates at birth probably reflect enhanced transplacental acquisition or decreased tissue uptake of carnitine in the preterm period. After birth, an abrupt cessation of carnitine supply from the materno-placental unit may predispose the immature neonates to carnitine deficiency and its adverse effects, particularly in the absence of an adequate exogenous carnitine intake in the postnatal period. A higher $\%$ of carnitine in blood is contained in the $\mathrm{RBC}$ than in plasma. Measurement of $\mathrm{RBC}[\mathrm{C}]$ is important in studies attempting to define the carnitine status.

\section{REFERENCES AND NOTES}

1. Babson, S. G. and Benda, G. I.: Growth graphs for the clinical assessment of infants of varying gestational age. J. Pediatr., 89: 814 (1976).

2. Bohmer, T.: Conversion of butyrobetaine to carnitine in the rat in vivo. Biochem. Biophys. Acta, 343: 551 (1974).

3. Borum, P. R.: Possible carnitine requirement of the newborn and the effect of genetic disease on the carnitine requirement. Nutr. Rev., 39: 385 (1981).

4. Borum, P. R. and York, C. M.: Red cell carnitine binding protein. Fed. Proc., 41 537 (Abstract 1559) (1982).

5. Cederblad, G. and Lindstedt, S.: A method for the determination of carnitine in the picomole range. Clin. Chim. Acta, 37: 235 (1972).

6. Chapoy, P. R., Angelini, C., Brown, W. J., Stiff, J. E., Shug, A. L., and Cederbaum, S. D.: Systemic carnitine deficiency -A treatable inherited lipidstorage disease presenting as Reye's syndrome. N. Engl. J. Med., 303: 1389 (1980).

7. Dubowitz, L. M. S., Dubowitz, V., and Goldberg, G.: Clinical assessment of gestational age in the newborn infants. J. Pediatr., 77: 1 (1970).
8. Fritz, I. B. and Marquis, N. R.: The role of acylcarnitine esters and carnitine palmitoyltransferase in the transport of fatty acyl groups across mitochondrial membranes. Proc. Natl. Acad. Sci. USA, 54: 1226 (1965).

9. Hahn, P.: The development of carnitine synthesis from $\gamma$-butyrobetaine in the rat. Life Sci., 29: 1057 (1981)

10. Hahn, P. and Skala, J.: The role of carnitine in brown adipose tissue of suckling rats. Comp. Biochem. Physiol., 51B: 507 (1975)

11. Hahn, P., Skala, J. P., Seccombe, D. W., Frohlich, J., Penn-Walker, D., Novak, M., Hynie, I., and Towell, M. E.: Carnitine content of blood and amniotic fluid. Pediatr. Res., 11: 878 (1977).

12. McGarry, J. D., Robles-Valdes, C. R., and Foster, D. W.: Role of carnitine in hepatic ketogenesis. Proc. Natl. Acad. Sci. USA, 72: 4385 (1975).

13. Mitchell, M. E.: Carnitine metabolism in human subjects. 1. Normal metabolism. Am. J. Clin. Nutr., 31: 293 (1978).

14. Novak, M., Monkus, E. F., Chung, D., and Buch, M.: Carnitine in the perinatal metabolism of lipids: I. Relationship between maternal and fetal plasma levels of carnitine and acyl carnitines. Pediatr. Res., 67: 95 (1981).

15. Novak, M., Wieser, P. B., Buch, M., and Hahn, P.: Acetylcarnitine and free carnitine in body fluids before and after birth. Pediatr. Res., 13: 10 (1979).

16. Pande, S.: A mitochondrial carnitine acylcarnitine translocase system. Natl. Acad. Sci. USA, 72: 883 (1975)

17. Penn, D., Schmidt-Sommerfeld, E., and Pascu, F.: Decreased tissue carnitine concentrations in newborn infants receiving total parenteral nutrition. J. Pediatr., 98: 976 (1981).

18. Persson, B., Settergren, G., and Dahiquist, G.: Cerebral arteriovenous difference of acetoacetate and $\beta$-OH-butyrate in children. Acta Paediatr. Scand., 61: 273 (1972).

19. Rebouche, C. J.: Comparative aspects of carnitine biosynthesis in microorganisms and mammals, with special attention to carnitine biosynthesis in man. In: $\mathbf{R}$. A. Frenkel, J. D. McGarry (Eds): Carnitine biosynthesis, Metabolism and Functions. Proceedings of the O'Hara Symposium on the Biosynthesis, Metabolism and Functions of Carnitine. New York, Academic Press, Inc., 1980, p. 57.

20. Robles-Valdes, C., McGarry, J. D., and Foster, D. W.: Maternal-fetal carnitine relationships and neonatal ketosis in the rat. J. Biol. Chem., 251: 6007 (1976)

21. Scholte, H. R., Stinis, J. T., and Jennekens, F. G. I.: Low carnitine levels in serum of pregnant women. N. Engl. J. Med., 299: 1079 (1979).

22. Shenai, J. P. and Borum, P. R.: Tissue carnitine reserves of very-low-birth-weight neonates. (In preparation).

23. Ware, A. J., Burton, W. C., McGarry, J. D., Marks, J. F., and Weinberg, A. G.: Systemic carnitine deficiency. J. Pediatr., 93: 959 (1978).

24. The authors gratefully acknowledge the expert technical assistance of Mrs. Carla M. York, Mrs. M. Collier, and Ms. Sandra G. Bennett.

25. This research was supported by Research Grants from The Nutrition Foundation, and The Muscular Dystrophy Association of America.

26. Requests for reprints should be addressed to: Dr. Jayant P. Shenai, Department of Pediatrics, Vanderbilt University Medical Center, Nashville, Tennesse 37232 (USA).

27. Received for publication April 14, 1982.

28. Accepted for publication October 14, 1982 